\title{
Comparison of buffet and à la carte serving at worksite canteens on nutrient intake and fruit and vegetable consumption
}

\author{
A Lassen ${ }^{1, *}, \mathrm{KS} \mathrm{Hansen}^{2}$ and E Trolle ${ }^{1}$ \\ 'Department of Nutrition, Danish Institute for Food and Veterinary Research, Søborg, Denmark: \\ ${ }^{2}$ Regional Veterinary and Food Control Centre Aarhus, Sønderskovvej 5, Lystrup, Denmark
}

Submitted 1 January 2006: Accepted 6 July 2006

\begin{abstract}
Objective: To evaluate the nutritional composition of worksite canteen lunches and to examine the impact of two meal serving systems on employee intake, i.e. buffet style with a fixed price for a varied number of dishes and à la carte style with a separate price for each item on the menu.

Design: Laboratory technicians observed employees' food selection and collected identical dishes. Food items were weighed separately to calculate the content of fruit and vegetables. The content of protein, fat and ash of each dish was chemically analysed and the carbohydrate and energy content calculated.

Setting: Fifteen randomly chosen worksite canteens in Denmark: eight canteens serving buffet style and seven canteens with an à la carte line.

Subjects: one hundred and eighty randomly chosen employees having lunch at the worksite canteens.

Results: The average percentage energy from fat was $37 \pm 12$ among men and $33 \pm 12$ among women. No association was found between the meal serving system and energy intake or macronutrient composition. Eating at canteens serving buffet style, on the other hand, was associated with an increased intake of fruit and vegetables, on average $76 \mathrm{~g}$, and a lower energy density of the food for both genders. Conclusion: The results highlight the possibilities of promoting healthy food choices in the catering sector and the need to identify models of healthy catering practice. Serving buffet style appears to be a promising strategy in order to increase fruit and vegetable consumption in food served away from home.
\end{abstract}

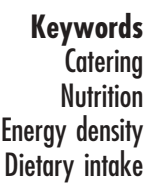

eywords

Catering ergy density Dietary intake
The catering sector plays an important and increasing role in relation to people's food intake in Western countries $^{1-4}$. The French Public Health Society concludes that without working closely with caterers, a nutrition policy is unlikely to be successful ${ }^{5}$. In particular, the worksite setting has the potential of providing access to nutritious foods for a wide range of the adult population through canteens, meal vouchers, vending machines offering healthy options or simply provision of bowls of fruit $^{6-8}$. However, relatively few studies deal with food selection and the nutritional quality of the food served away from home, and little is known about strategies to increase the nutritional value of the meals and encourage people to make healthier food choices ${ }^{4,9}$.

While some dietary interventions in both the worksite and school settings have been quite promising in influencing employees and pupils to purchase and consume more healthy meals ${ }^{10-13}$, other studies have been less positive ${ }^{14-16}$. The most effective ways of achieving dietary changes seem to be increasing the accessibility and appeal of healthy choices rather than promoting 'healthier' menu items through nutrition labelling ${ }^{17,18}$. In addition, food pricing has been suggested to be an effective tool to affect food choices, and large effects of price reduction on sales of fresh fruits and vegetables in two school cafeterias have been demonstrated $^{19,20}$. It is also likely that the meal service system influences the selection and hence consumption of different menu items offered in catering establishments. The worksite canteens in Denmark normally use one of two different selfservice styles; either mainly buffet style or an à la carte line. The aims of the present study were to (1) evaluate the nutritional composition of worksite canteen lunch intake with regard to energy intake, energy density, macronutrients and the content of fruit and vegetables; and (2) examine the impact of two different meal serving systems on employee food choices and nutrient intake, i.e. buffet style with a fixed price for a varied number of dishes and à la carte style with a separate price for each item on the menu.

\section{Methods}

The recruitment took place in two steps. A total of 23 worksites with in-house catering facilities representing 
both city (Aarhus) and provincial towns were asked to participate in a survey describing the menus and serving system in the canteen. The worksites were extracted at random from a central national register. Worksite information was obtained on size, occupation (percentage physically active), sex distribution and canteen serving system to make sure that the final distribution would match that of the country as a whole. Two worksites refused to participate because of lack of time and one worksite was excluded to match the desired average distribution. A total of 20 worksites agreed to participate. Afterwards the 20 worksites were asked to participate in the present study focusing on individual canteen food intake. Five of the 20 worksites refused to participate for the following reasons: lack of time (three worksites) or concerns regarding the employees' reaction to the study (two worksites). Eight of the worksites that agreed to participate mainly served buffet style and seven of the worksites served an à la carte line. Data collection took place between February and November.

The duplicate-portion technique with subsequent chemical analysis was used to quantify actual lunch intakes at the worksite canteens. Double portions were collected from a total of 12 customers at each canteen on two different days (six samples per day). Employees were asked at random if they would participate in the study, and two people at most at each canteen declined to participate. Dishes identical to those selected by the employees were observed and collected by laboratory technicians. Both the original and the duplicate portions were photographed. After the employees had finished eating their lunch, they were asked to return the plates to the technicians in order to record plate waste. Food items on each dish, excluding plate waste, were weighed separately. Recipes and methods for dish preparation were provided by the staff of the canteens, thereby providing the basis for the calculation of the fruit and vegetable content of each dish. Beverages were not included in the analysis.

The portions were individually mixed and homogeneously blended. Analyses of the content of protein, fat and ash were performed according to procedures given by the Nordic Committee on Food Analysis ${ }^{21-23}$. Dry matter content was determined by drying in a vacuum oven at $70^{\circ} \mathrm{C}$ to constant weight. Carbohydrate and energy content were calculated from contents of dry matter, protein, fat and $\mathrm{ash}^{24}$.

The participants in the survey were asked questions about their age, weight, height, employment, their attitudes towards eating healthy food, satisfaction with the canteen food and finally if the tested meal was a typical meal. The question 'Do you try to eat healthy foods?' could be answered as follows: 'very often/always', 'often', 'sometimes', 'seldom/never' or 'don't know'. The question 'Overall, how satisfied are you with the cafeteria food?' could be answered on a 5-point rating scale from $1=$ 'very dissatisfied' to $5=$ 'very satisfied'. Finally, the question 'Does the actual meal resemble your usual meal?' could be answered as follows: 'yes totally', 'yes almost' or 'no not very much'.

\section{Data analysis}

Body mass index was calculated from self-reported height and weight data. Intake of fruit and vegetables was expressed in terms of both gram per meal and per $10 \mathrm{MJ}$. Dishes were categorised into three groups: (1) hot meals or sandwiches (mainly open sandwiches) only; (2) salad only; and (3) a combination of hot meals/sandwiches and salad/fruit/snack vegetables.

SPSS version 13.0 was used for the data analysis. Analyses were conducted separately for men and women, with the individual employee being the unit of analysis. Continuous variables were compared using the independent samples $t$-test when the data were distributed normally, i.e. age; and the Mann-Whitney $U$-test when data were skewed, i.e. body mass index, satisfaction score and measures of food and nutrient intake. The $\chi^{2}$ test with Yates continuity correction was used to compare discrete data variables, i.e. the prevalence of white collar employees and positive answers to the question 'Do you try to eat healthy foods?' Statistical significance was assigned to a $P$-value of $<0.05$.

\section{Results}

Most of the respondents (94\%) answered 'yes totally' or 'yes almost' to the question: 'Does the actual meal resemble your usual meal?' while 6\% answered 'no not very much' to the question. No significant differences were found between employees having lunch at canteens serving buffet style and those having lunch at canteens with an à la carte line with respect to the tested background variables: age, body mass index, prevalence of white collar employees, satisfaction with the canteen food or how often they try to eat healthy foods. However, attitudes toward eating healthy food varied significantly by gender, as $80 \%$ of the women and only $48 \%$ of the men claimed that they often or very often tried to eat healthy foods ( $P<0.001$; not shown). Also, men had a higher calculated body mass index compared with women $\left(25.3 \pm 3.3\right.$ vs. $23.5 \pm 3.9 \mathrm{~kg} \mathrm{~m}^{-2}, \quad P<0.001$, not shown). Sixty-two per cent of all employees were white collar workers, average age was $40 \pm 9$ years and average satisfaction score was $4.2 \pm 0.8$ (not shown).

The nutrient intake is summarised in Table 1 by gender and meal serving system. No associations were detected between style of meal service and either energy intake or macronutrient distribution. The average lunch of the participating employees had $45 \pm 13 \%$ of the energy from carbohydrates, $20 \pm 7 \%$ from protein and $35 \pm 12 \%$ from fat (Table 1). The average percentage of energy from fat was $37 \pm 12$ among men and $33 \pm 12$ among women $(P<0.05$, not shown). Two-thirds of all dishes contained $>30 \%$ energy from fat (not shown). 
Table 1 Lunch intake at staff canteens of energy, macronutrients, fruit and vegetables for men and women by meal serving system

\begin{tabular}{|c|c|c|c|c|c|c|c|}
\hline & \multicolumn{2}{|c|}{ Men } & \multicolumn{3}{|c|}{ Women } & \multirow[b]{3}{*}{$P$-value } & \multirow{3}{*}{$\begin{array}{l}\text { All }(n=180) \\
\text { Mean } \pm \text { SD }\end{array}$} \\
\hline & $\begin{array}{l}\text { Buffet style* } \\
\quad(n=56)\end{array}$ & $\begin{array}{c}\text { À la carte line } \dagger \\
\quad(n=53)\end{array}$ & \multirow[b]{2}{*}{$P$-value } & $\begin{array}{l}\text { Buffet style* } \\
\quad(n=40)\end{array}$ & $\begin{array}{c}\text { À la carte line } \dagger \\
\quad(n=31)\end{array}$ & & \\
\hline & $\overline{\text { Mean } \pm S D}$ & Mean \pm SD & & $\overline{\text { Mean } \pm \text { SD }}$ & Mean \pm SD & & \\
\hline Energy (kJ per meal) & & $2851 \pm 1259$ & 0.111 & $1909 \pm 557$ & $2065 \pm 840$ & 0.458 & $2392 \pm 999$ \\
\hline Energy (kcal per meal) & $(593 \pm 200)$ & $(681 \pm 301)$ & & $(456 \pm 133)$ & $(493 \pm 201)$ & & $(572 \pm 239)$ \\
\hline Portion size (g per meal) & $388 \pm 116$ & $386 \pm 155$ & 0.823 & $345 \pm 95$ & $283 \pm 77$ & 0.003 & $360 \pm 125$ \\
\hline Energy density $\left(\mathrm{kJ}_{\left.100 \mathrm{~g}^{-1}\right)}\right.$ & $654 \pm 176$ & $787 \pm 295$ & 0.039 & $568 \pm 155$ & $732 \pm 179$ & $<0.001$ & $688 \pm 228$ \\
\hline Energy density (kcal $100 \mathrm{~g}^{-1}$ ) & $(156 \pm 42)$ & $(188 \pm 70)$ & & $(136 \pm 37)$ & $(175 \pm 43)$ & & $(164 \pm 55)$ \\
\hline Carbohydrate (E\%) & $43 \pm 14$ & $44 \pm 11$ & 0.517 & $47 \pm 12$ & $47 \pm 12$ & 0.889 & $45 \pm 13$ \\
\hline Protein (E\%) & $21 \pm 8$ & $18 \pm 5$ & 0.165 & $20 \pm 8$ & $20 \pm 7$ & 0.772 & $20 \pm 7$ \\
\hline Fat $(\mathrm{E} \%)$ & $36 \pm 12$ & $38 \pm 12$ & 0.658 & $33 \pm 12$ & $33 \pm 13$ & 0.835 & $35 \pm 12$ \\
\hline Fat (g per meal) & $25 \pm 14$ & $29 \pm 17$ & 0.184 & $17 \pm 8$ & $19 \pm 13$ & 0.899 & $23 \pm 15$ \\
\hline Vegetables and fruitł (g per meal) & $143 \pm 101$ & $65 \pm 63$ & $<0.001$ & $174 \pm 98$ & $103 \pm 61$ & $<0.001$ & $120 \pm 94$ \\
\hline Vegetables $\ddagger$ (g per meal) & $118 \pm 76$ & $59 \pm 56$ & $<0.001$ & $143 \pm 77$ & $88 \pm 58$ & 0.002 & $101 \pm 75$ \\
\hline Fruit (g per meal) & $25 \pm 41$ & $7 \pm 23$ & $<0.001$ & $31 \pm 45$ & $15 \pm 29$ & 0.047 & $19 \pm 37$ \\
\hline Vegetables and fruitł $\left(\mathrm{g} 10 \mathrm{MJ}^{-1}\right)$ & $655 \pm 552$ & $291 \pm 355$ & $<0.001$ & $971 \pm 577$ & $572 \pm 393$ & 0.001 & $604 \pm 537$ \\
\hline Vegetables $\neq\left(\mathrm{g} 10 \mathrm{MJ}^{-1}\right)$ & $553 \pm 470$ & $261 \pm 312$ & $<0.001$ & $812 \pm 497$ & $491 \pm 387$ & 0.001 & $514 \pm 463$ \\
\hline Fruit $\left(\mathrm{g} 10 \mathrm{MJ}^{-1}\right)$ & $102 \pm 170$ & $30 \pm 115$ & $<0.001$ & $159 \pm 234$ & $81 \pm 183$ & 0.024 & $90 \pm 180$ \\
\hline
\end{tabular}

$n$ - number of employees; SD - standard deviation; E\% - percentage of energy.

Significant differences are highlighted in bold $(P \leq 0.05)$.

${ }^{*}$ Allow employees to pick and choose from a selection of different options for a fixed price.

† Employees pay for each item individually.

$\ddagger$ Excluding potatoes.

Being a woman having lunch at canteens serving buffet style was significantly associated with eating larger food portion sizes $(P=0.003)$ with a lower energy density $(P<0.001)$ compared with canteens with an à la carte line, while energy intake did not differ significantly between groups (Table 1). With regard to the men, the energy density was significantly lower among those having lunch at canteens serving buffet style $(P=0.039)$, whereas average portion size did not differ depending on the meal serving system.

For both genders, lunch at canteens serving buffet style was associated with a significantly greater likelihood of consuming more fruit and vegetables $\left(P<0.001\right.$; g per meal and $\left.\mathrm{g} 10 \mathrm{MJ}^{-1}\right)$. On average, the men and women eating in canteens serving buffet style consumed $143 \pm 101$ and $174 \pm 98 \mathrm{~g}$ of fruit and vegetables per meal, respectively (Table 1), corresponding to 78 and $71 \mathrm{~g}$ more, respectively, compared with those having lunch at canteens with an à la carte line (76g more on average).
The pattern of food selection according to meal serving system is shown in Table 2. More employees having lunch at canteens serving buffet style selected a combination of different options including salad, fruit or snack vegetables (men and women: 63 and 75\%, respectively, Table 2) compared with those having lunch at canteen with an à la carte line (men and women: 19 and 35\%, respectively, Table 2), rather than eating either hot meals or sandwiches as the sole selection.

\section{Discussion}

In this study of lunch intake in Danish worksite canteens, we found that eating at worksite canteens serving buffet style was significantly associated with an increased intake of fruit and vegetables compared with eating at canteens with an à la carte serving line. On average, employees having lunch at buffet-style canteens consumed $76 \mathrm{~g}$ more fruit and vegetables per lunch than those having an à la carte lunch. It is notable that the same pattern was found across

Table 2 Male and female employees' selection of different meal options, e.g. hot meals or sandwiches only, salad as sole selection or a combination of hot meals/sandwiches and salad/fruit/snack vegetables in relation to the meal serving system

\begin{tabular}{|c|c|c|c|c|c|}
\hline & \multicolumn{2}{|c|}{ Men } & \multicolumn{2}{|c|}{ Women } & \multirow[b]{2}{*}{ All $(n=180)$} \\
\hline & $\begin{array}{l}\text { Buffet style }^{*} \\
\quad(n=56)\end{array}$ & $\begin{array}{c}\text { À la carte line } \dagger \\
(n=53)\end{array}$ & $\begin{array}{l}\text { Buffet style* } \\
\quad(n=40)\end{array}$ & $\begin{array}{c}\text { À la carte line } \dagger \\
\quad(n=31)\end{array}$ & \\
\hline Hot meals or sandwiches only (\%) & 27 & 79 & 8 & 45 & 41 \\
\hline Salad only (\%) & 11 & 2 & 18 & 19 & 11 \\
\hline Combination including salad and/or fruit (\%) & 63 & 19 & 75 & 35 & 48 \\
\hline
\end{tabular}

$n$ - number of employees.

${ }^{*}$ Allow employees to pick and choose from a selection of different options for a fixed price.

† Employees pay for each item individually. 
genders, despite the fact that men compared with women generally consume less fruit and vegetables, as shown in this and other studies, and are less health conscious ${ }^{25-27}$. The differences in fruit and vegetable consumption are comparable with the results of an intervention trial among employees including both individually tailored health messages and a helpers programme at the worksite ${ }^{28}$, and another including peer education to achieve an increase in fruit and vegetable intake ${ }^{29}$. The Seattle 5 a Day Worksite Program focusing solely on changes in fruit and vegetable consumption in a wide range of worksite types, all with cafeterias, revealed an average increase of 0.4 servings in the intervention worksites from plate observation at cafeteria checkout lines ${ }^{13}$

The present results suggest that the different patterns of food selection according to the meal serving system may account for some of the differences in lunch intake of fruit and vegetables. Serving buffet-style lunches seems to encourage people to combine different options, including salad, fruit and snack vegetables, and may increase the variety of the composed meal. Another possible benefit of serving buffet style is that the resources needed for cash handling may be diminished, enabling resources to be reallocated to prepare larger proportions of fruit and vegetables. It is important, however, that both canteens serving buffet style and à la carte lines focus on increasing fruit and vegetable content in the different meal options and at the same time try to limit the total energy intake.

Canteens with an à la carte line might be modified to promote fruit and vegetable intake without changing their serving style completely. Potential strategies to increase fruit and vegetable consumption could be selling a meal together with salad and fruit at a fixed price which is lower than the total of the à la carte prices of the same items. In a Danish canteen intervention study, an à la carte worksite canteen successfully offered a cold plate daily with a fixed amount of fruit and vegetables, e.g. $200 \mathrm{~g}$ of fruit and vegetables, including salads and half a piece of fruit ${ }^{12}$. Other obvious factors that can be affected are reducing the availability and attractiveness of competing unhealthy food options. Competitive food sold outside school meal programmes has been shown to affect students' food choices negatively $^{30,31}$, as the most popular choices are often foods with low nutritional value ${ }^{32}$.

The present results demonstrate, surprisingly, that the energy intake per lunch meal for both men and women is the same for both of the two different meal serving systems. Research has suggested that greater dietary variety is associated with greater food intake ${ }^{33,34}$. The present results showed that women chose larger food portions at buffet-style canteens offering a variety of foods for a fixed price but, since energy density at the same time was significantly lower, energy intake remained constant. The lower energy density was due to the increased amount of fruits and vegetables high in water and volume but providing less energy. It is likely that the energy density of foods is a key determinant of energy intake $\mathrm{e}^{35}$. It has been found that when subjects ate a large portion of low-energy dense salad as a first course, energy intake for the entire meal was minimised ${ }^{36,37}$.

The Nordic Nutrition Recommendations state that fat should provide $25-35 \%$ of the total energy intake and that the population goal is $30 \%^{38}$. In the present study, no relationship was found between fat content and the style of meal service. The average percentage of energy from fat was $37 \pm 12$ among men and $33 \pm 12$ among women. This is in line with the average percentage of fat found in the total diet among men and women in the Danish National Dietary Survey 2000-2002 when the contribution of energy from alcohol is excluded from the calculations ${ }^{39}$. Also, data on average fat content expressed as gram per meal were in agreement with data from a study performed in Germany analysing staff canteen meals over a period of 1 year ${ }^{40}$. On the contrary, a study performed in Croatia showed that $88 \%$ of the meals offered at students' restaurants provided a balanced intake of macronutrients ${ }^{41}$.

The present study had both strengths and limitations. Strengths included that findings of employee lunch intake were based on portions that were weighed and analysed separately rather than on self-reported information. In addition, the survey imposed a minimum response burden on the employees, resulting in a high response rate. However, it cannot be excluded that the worksite canteens may have modified their meals slightly because of the survey and that employees may have changed their food choice behaviour on account of their meal being documented. Beverages were not included in this study, as the relationship between energy density and macronutrient content of beverages is more complex than that of individual foods or diets ${ }^{42}$. Beverages, however, can make a significant contribution to the total energy intake of an individual ${ }^{42}$. Finally, no data are available on pricing of worksite lunches paid for individually by the employees. However, food choice is likely to be influenced by the price of the meal. Results from the first step of the recruitment survey showed that price variation was rather modest when purchasing meals in canteens serving buffet style compared with a larger variation when purchasing individual food items in canteens serving à la carte menu ${ }^{43}$.

In conclusion, the results highlight the possibilities of promoting healthy food choices in the catering sector. The results also indicate the need for identifying models of healthy catering practice. There are a number of specific implications from this survey for improving canteen lunches. Attention should be paid to lowering the energy density of the food, motivating the employees to eat more fruits and vegetables, and lowering the fat content of the food without compromising the appearance or taste. 
Serving buffet-style meals including a variety of fruit and vegetables appears to be a promising strategy in order to increase fruit and vegetable consumption from food served away from home.

\section{Acknowledgements}

The authors would like to thank the employees who took part in this survey, the worksite canteens for their cooperation and the laboratory staff for collecting the samples and performing the laboratory analyses. We also thank Leif Bøgh-Sørensen, Anja Biltoft-Jensen, Lene Møller Christensen, Anne Vibeke Thorsen and Inge Tetens, all from the Danish Institute for Food and Veterinary Research, for their advice, support and manuscript review.

\section{References}

1 Burns C, Jackson M, Gibbons C, Stoney RM. Foods prepared outside the home: association with selected nutrients and body mass index in adult Australians. Public Health Nutrition 2002; 5: 441-8.

2 Guthrie JF, Lin BH, Frazao E. Role of food prepared away from home in the American diet, 1977-78 versus 1994-96: changes and consequences. Journal of Nutrition Education and Behavior 2002; 34: 140-50.

3 Nielsen SJ, Siega-Riz AM, Popkin BM. Trends in food locations and sources among adolescents and young adults. Preventive Medicine 2002; 35: 107-13.

4 Roos E, Sarlio-Lahteenkorva S, Lallukka T. Having lunch at a staff canteen is associated with recommended food habits. Public Health Nutrition 2004; 7: 53-61.

5 Société Française de Santé Publique. Health and Human Nutrition: Elements for European Action. France: Collection Santé \& Société, 2000.

6 Katz DL, O'Connell M, Yeh M-C, Nawaz H, Nijke V, Anderson LM, et al. Public health strategies for prevention and controlling overweight and obesity in school and worksite settings: a report on recommendations of the Task Force on Community Preventive Services. Morbidity and Mortality Weekly Report. Recommendations and Reports 2005; 54(RR10): $1-12$.

7 Buttriss J, Stanner S, McKevith AP, Nugent C, Kelly C, Phillps F, et al. Successful ways to modify food choice: lessons from the litterature. Nutrition Bulletin 2004; 29: $333-43$.

8 Wanjek C. Food at Work: Workplace Wolutions for Malnutrition, Obesity and Chronic Diseases. Switzerland: International Labour Organisation, 2005.

9 Glanz K, Hoelscher D. Increasing fruit and vegetable intake by changing environments, policy and pricing: restaurantbased research, strategies, and recommendations. Preventive Medicine 2004; 39(Suppl. 2): S88-93.

10 Story M, Snyder MP, Anliker J, Weber JL, Cunningham-Sabo $\mathrm{L}$, Stone EJ, et al. Changes in the nutrient content of school lunches: results from the Pathways study. Preventive Medicine 2003; 37: S35-45.

11 Osganian SK, Ebzery MK, Montgomery DH, Nicklas TA, Evans MA, Mitchell PD, et al. Changes in the nutrient content of school lunches: results from the CATCH Eat Smart Food Service Intervention. Preventive Medicine 1996; 25: 400-12.

12 Lassen A, Thorsen AV, Trolle E, Elsig M, Ovesen L. Successful strategies to increase the consumption of fruits and vegetables: results from the Danish ' 6 a day' Work-site
Canteen Model Study. Public Health Nutrition 2004; 7: 263-70.

13 Beresford SA, Thompson B, Feng Z, Christianson A, McLerran D, Patrick DL. Seattle 5 a Day worksite program to increase fruit and vegetable consumption. Preventive Medicine 2001; 32: 230-8.

14 Parker L, Fox A. The Peterborough Schools Nutrition Project: a multiple intervention programme to improve school-based eating in secondary schools. Public Health Nutrition 2001; 4 : $1221-8$.

15 Steenhuis I, Van AP, Van BG, Glanz K, Kok G, De VH. The impact of educational and environmental interventions in Dutch worksite cafeterias. Health Promotion International 2004; 19: 335-43.

16 Steenhuis I, Van AP, Reubsaet A, Kok G. Process evaluation of two environmental nutrition programmes and an educational nutrition programme conducted at supermarkets and worksite cafeterias in the Netherlands. Journal of Human Nutrition and Dietetics 2004; 17: 107-15.

17 EURODIET Core Report. Nutrition and diet for healthy lifestyles in Europe: science and policy implications. Public Health Nutrition 2000; 4: 265-73.

18 Stubenitsky K, Aaron J, Catt S, Mela D. The influence of recipe modification and nutritional information on restaurant food acceptance and macronutrient intakes. Public Health Nutrition 2000; 3: 201-9.

19 French SA. Pricing effects on food choices. Journal of Nutrition 2003; 133: 841S-3S.

20 French SA. Public health strategies for dietary change: schools and workplaces. Journal of Nutrition 2005; 135: 910-2.

21 Nordic Committee on Food Analysis (NMKL). Nitrogen. Determination in Foods and Feeds According to Kjeldahl. Method No. 6, 4th ed. Oslo: NMKL, 2003.

22 Nordic Committee on Food Analysis (NMKL). Fat. Determination in Foods. Method No. 160. Oslo: NMKL, 1998.

23 Nordic Committee on Food Analysis (NMKL). Ash. Gravimetric Determination in Foods. Method No. 128. Oslo: NKML, 1989

24 Saxholt E, Møller A. Food Composition Tables, 4th ed. Copenhagen: National Food Agency of Denmark, 1996 (in Danish).

25 Ashfield-Watt PA, Welch AA, Day NE, Bingham SA. Is 'five-aday' an effective way of increasing fruit and vegetable intakes? Public Health Nutrition 2004; 7: 257-61.

26 Baker AH, Wardle J. Sex differences in fruit and vegetable intake in older adults. Appetite 2003; 40: 269-75.

27 Friel S, Newell J, Kelleher C. Who eats four or more servings of fruit and vegetables per day? Multivariate classification tree analysis of data from the 1998 Survey of Lifestyle, Attitudes and Nutrition in the Republic of Ireland. Public Health Nutrition 2005; 8: 159-69.

28 Campbell MK, Tessaro I, DeVellis B, Benedict S, Kelsey K, Belton L, et al. Effects of a tailored health promotion program for female blue-collar workers: health works for women. Preventive Medicine 2002; 34: 313-23.

29 Buller DB, Morrill C, Taren D, Aickin M, Sennott-Miller L, Buller MK, et al. Randomized trial testing the effect of peer education at increasing fruit and vegetable intake. Journal of the National Cancer Institute 1999; 91: 1491-500.

30 Kubik MY, Lytle LA, Hannan PJ, Perry CL, Story M, et al. The association of the school food environment with dietary behaviors of young adolescents. American Journal of Public Health 2003; 93: 1168-73.

31 Probart C, McDonnell E, Hartman T, Weirich JE, Bailey-Davis L. Factors associated with the offering and sale of competitive foods and school lunch participation. Journal of the American Dietetic Association 2006; 106: 242-7.

32 Harnack L, Snyder P, Story M, Holliday R, Lytle L, NewmarkSztainer D. Availability of a la carte food items in junior and 
senior high schools: a needs assessment. Journal of the American Dietetic Association 2000; 100: 701-3.

33 Raynor HA, Jeffery RW, Phelan S, Hill JO, Wing RR. Amount of food group variety consumed in the diet and long-term weight loss maintenance. Obesity Research 2005; 13: 883-90.

34 McCrory MA, Fuss PJ, McCallum JE, Yao M, Vinken AG, Hays NP, et al. Dietary variety within food groups: association with energy intake and body fatness in men and women. American Journal of Clinical Nutrition 1999; 69: 440-7.

35 Prentice AM, Jebb SA. Fast foods, energy density and obesity: a possible mechanistic link. Obesity Reviews 2003; 4: 187-94.

36 Rolls BJ, Roe LS, Meengs JS. Salad and satiety: energy density and portion size of a first-course salad affect energy intake at lunch. Journal of the American Dietetic Association 2004; 104: $1570-6$

37 Ello-Martin JA, Ledikwe JH, Rolls BJ. The influence of food portion size and energy density on energy intake: implications for weight management. American Journal of Clinical Nutrition 2005; 82: 236S-41S.

38 Becker W, Lyhne N, Pedersen AN, Aro A, Fogelholm M, Phorsdottir I, et al. Nordic Nutrition Recommendations
2004 - integrating nutrition and physical activity. Scandinavian Journal of Nutrition 2004; 48: 178-87.

39 Andersen NL, Christensen T, Groth M, Fagt S, Biltoft-Jensen A, Hartkopp HB, et al. Dietary Habits in Denmark 20002002. Main Results, 11th ed. Søberg: Danmarks Fødevareforskning, 2005 (in Danish).

40 Mayer R. PCDD/F levels in food and canteen meals from Southern Germany. Chemosphere 2001; 43: 857-60.

41 Baric IC, Satalic Z, Lukesic Z. Nutritive value of meals, dietary habits and nutritive status in Croatian university students according to gender. International Journal of Food Sciences and Nutrition 2003; 54: 473-84.

42 Crowe TC, La Fontaine HA, Gibbons CJ, Cameron-Smith D, Swinburn BA. Energy density of foods and beverages in the Australian food supply: influence of macronutrients and comparison to dietary intake. European Journal of Clinical Nutrition 2004; 58: 1485-91.

43 Hansen KS, Lassen A. KantineMåltider - Undersøgelse af Udbud og Sortiment i 20 Danske Arbejdskantiner. Søborg: Danmarks Fødevareforskning, 2004 (in Danish). 